\title{
A REPRESENTAÇÃO DO SUJEITO DIASPÓRICO EM O LIVRO DOS NEGROS, DE LAWRENCE HILL
}

\author{
Shirley de Souza Gomes Carreira ${ }^{1 *}$ \\ ${ }^{1}$ Universidade do Estado do Rio de Janeiro, Rio de Janeiro, RJ, Brasil
}

\begin{abstract}
Resumo
As neonarrativas de escravidão surgiram no cenário literário norte-americano com a publicação de Jubilee, de Margaret Walker (1966), porém só tiveram efetivo reconhecimento nos anos oitenta, com o lançamento de Beloved, de Toni Morrison (1987). Concebidas como "romances contemporâneos que assumem a forma, as convenções e a voz narrativa em primeira pessoa das narrativas de escravos produzidas antes da Guerra Civil" (RUSHDY, 1997), foram, aos poucos, se distanciando desse modelo e hoje podem ser consideradas transnacionais e globais, bem como dialógicas, polifônicas e transgenéricas, segundo Judith Misrahi-Barak (2014). Nessa perspectiva e com o suporte teórico dos Estudos Culturais e do conceito pós-moderno de metaficção historiográfica, este trabalho propõe a análise da representação do sujeito diaspórico em O livro dos negros, do canadense Lawrence Hill (2014), que tem por temática a trajetória de escravos durante a vigência do sistema escravagista. Ao deslocar a voz narrativa para o oprimido, Hill desafia o discurso da História, escovando-a a contrapelo. Palavras-chave: Sujeito diaspórico; Neonarrativa de escravidão contemporânea; O livro dos negros
\end{abstract}

\section{THE REPRESENTATION OF THE DIASPORIC SUBJECT IN THE BOOK OF NEGROES, BY LAWRENCE HILL}

\begin{abstract}
Neo-slave narratives emerged on the American literary scene with the publication of Jubilee, by Margaret Walker (1966), but only had effective recognition in the 1980s, with the release of Beloved, by Toni Morrison (1987). Conceived as "contemporary novels that assume the form, adopt the conventions and take on the first-person voice of antebellum slave narrative" (RUSHDY, 1997), according to Judith Misrahi-Barak (2014), they were gradually distancing themselves from this model and today they
\end{abstract}

\footnotetext{
* Doutora em Literatura Comparada pela Universidade Federal do Rio de Janeiro (UFRJ) com estágio PósDoutoral em Literaturas de Língua Inglesa pela Universidade do Estado do Rio de Janeiro (UERJ). Atualmente, é professora adjunta do Departamento de Letras da Faculdade de Formação de Professores da UERJ e do Programa de Pós-Graduação em Letras e Linguística (PPLIN) na mesma instituição. Líder do grupo de pesquisa Poéticas da diversidade, cadastrado no CNPq. Procientista UERJ/FAPERJ. Seu e-mail: shirleysgcarr@ gmail.com. ORCID: https://orcid.org/0000-0002-8787-823.
} 
can be considered transnational and global, as well as dialogic, polyphonic and transgenic. In this perspective and with the support of Cultural Studies and the postmodern concept of historiographic metafiction, this work proposes the analysis of the representation of the diasporic subject in The Book of Negroes, by the Canadian author Lawrence Hill (2014), which has as its theme the trajectory of slaves during the validity of the slave system. By shifting the narrative voice to the oppressed, Hill challenges the discourse of history, brushing it against the grain.

Keywords: Diasporic subject; Contemporary Neo-slave narratives; The book of negroes 


\section{Breve reflexão sobre as neonarrativas de escravidão}

Ao propor a análise da representação do sujeito diáspórico em uma obra que se caracteriza como neonarrativa de escravidão contemporânea, buscamos, em primeiro lugar, reiterar o caráter transnacional e global dessas narrativas conforme a perspectiva de Misrahi-Barak (2014), que as considera como um desdobramento da versão original do gênero, definido por Rushdy (1997, p. 3) como "romances contemporâneos que adotam a forma, as convenções e a voz narrativa em primeira pessoa das narrativas de escravos anteriores à guerra civil".

As primeiras narrativas de escravos (slave narratives) surgiram nos Estados Unidos ainda durante o período da escravidão e, em sua maioria, são biografias de escravos que, de algum modo, conseguiram chegar ao norte do país, conquistando a liberdade, dentre eles, Frederick Douglas e Harriet Jacobs. Foi por meio dessas narrativas que o movimento abolicionista procurou conscientizar o povo das atrocidades cometidas sob a égide do sistema escravocrata (NAKANISHI; NIGRO, 2019). Entretanto, depois da guerra, tendo a sua credibilidade e autenticidade questionadas, essas narrativas caíram no esquecimento (TORRES; PAIVA, 2019).

Segundo Rushdy (1997, p. 3), na década de 1960, graças a uma mudança de enfoque nos estudos acadêmicos sobre o passado dos Estados Unidos - e consequentemente da historiografia sobre a escravidão -, aliada aos movimentos sociais da época, em especial ao Black Power, as narrativas de escravos se tornaram objeto de estudo nas universidades.

Nesse mesmo período, em meio à luta por direitos civis, Jubilee, de Margaret Walker (1966), foi publicado, inaugurando uma nova vertente que Bernard Bell, em The Afro- American Novel and Its Tradition (1987), denominou "neo-slave narratives", ou seja, romances que se ambientavam no período escravagista e guardavam alguns traços das "slave narratives", como, por exemplo, as marcas de oralidade (DAVIS; GATES, 1991), apresentando, entretanto, características distintivas. Ao invés do caráter informativo que predominava nos textos escritos por escravos, elas introduziram inovações formais que buscavam convocar a interpretação do leitor. Segundo Misrahi-Barak (2014), seu efetivo reconhecimento ocorreu apenas após o lançamento de Beloved, de Toni Morrison, em 1987, considerado um divisor de águas.

$\mathrm{Na}$ última década do século XX, houve uma espécie de boom das neonarrativas de escravidão, que não mais se restringiam ao contexto afro-americano, expandindo-se e adotando formatos e abordagens diferenciados, abrindo espaço à polifonia e ao hibridismo textual.

É nesse contexto que este trabalho propõe a análise da representação do sujeito diaspórico em O livro dos negros, do canadense Lawrence Hill (2014), enfatizando não apenas o olhar crítico sobre a escravidão, como também buscando evidenciar a reconfiguração identitária dos sujeitos em diáspora, o processo de tradução cultural e o impacto do cativeiro na configuração identitária dos escravos e dos seus descendentes. 


\section{O diálogo entre literatura e história em $O$ livro dos negros}

Lawrence Hill, autor de O livro dos negros, é canadense e filho de imigrantes ativistas dos direitos civis. Seu pai, Daniel G. Hill, foi um sociólogo afro-americano, descendente de pastores metodistas episcopais que foram escravos nos Estados Unidos. A influência dos pais foi determinante para a visão de Hill sobre a migração e as questões de identidade e pertencimento.

O livro dos negros foi publicado pela primeira vez em 2007 e obteve ampla repercussão, a ponto de inspirar uma minissérie filmada pela BBC. Devido a uma possível sensibilidade à palavra "negro" no título da edição canadense, a publicação foi intitulada Someone Knows My Name (Alguém conhece o meu nome) nos Estados Unidos, Austrália e Nova Zelândia.

O romance é especialmente relevante por abordar uma questão que tem sido ignorada pelos pesquisadores em geral: o papel do Canadá na diáspora africana. Ao elaborar uma obra que não apenas desloca a voz narrativa para o oprimido, mas também traz à baila, ainda que pela via da ficção, parte dessa história desconhecida do grande público, Hill usa uma estratégia definida por Linda Hutcheon (1991) como metaficção historiográfica - ou seja, a apropriação ficcional de personagens e/ou acontecimentos históricos para problematizá-los -, que constitui seu recurso para escovar a história a contrapelo (BENJAMIN, 1987).

Hill revisita o arquivo histórico - que é um documento de cultura, mas também de barbárie -, suplementando-o, pois, no arquivo colonial britânico, não há espaço para a voz do escravo. Conforme sinaliza Johnson, a narrativa histórica sobre o comércio de escravos é feita do ponto de vista daqueles que o controlam (JOHNSON, 2014, p. 155). O romance de Hill é, portanto, uma resposta à violência epistêmica do arquivo colonial.

O título do livro se reporta a um documento histórico, "O livro dos negros", um registro de escravos que colaboraram com a coroa durante a Revolução Americana ${ }^{1}$ (1775-1783). Em agradecimento a esse apoio, muitos deles foram alforriados. No romance, o registro desses nomes cabe a uma escrava, a narradora Aminata Diallo, que se distingue dos demais por saber ler, falar e escrever muito bem em inglês.

Ao mesmo tempo em que se configura como um registro de memórias, o romance traz para o centro da narrativa uma personagem que é representativa das vítimas do sistema escravocrata, incorporando uma das características das narrativas de escravidão retomadas na contemporaneidade.

De acordo com Rushdy (1997, p. 90), há três subgêneros de neonarrativas de escravidão revisionistas contemporâneas: (1) o romance histórico sobre a escravidão (2) os romances que narram os efeitos da escravidão vivenciados por americanos contemporâneos; e (3) a narrativa genealógica que abrange a história de uma família de descendentes de escravos. O livro dos negros se enquadra na primeira categoria, sem, no entanto, se privar de incursões na última, uma vez que a obra nos permite acompanhar o destino da descendência da protagonista.

Em grande parte, o romance explora a tradição das narrativas de escravos, utilizando a linguagem e os tropos do gênero, como, por exemplo, o fato de a nar- 
radora ser uma escrava que adquire literacia e liberdade, fazendo uso de ambas para colocar-se a serviço da causa abolicionista.

Boa parte da trama se desenrola nos Estados Unidos e na Nova Escócia, que atualmente é uma província do Canadá. Durante a Revolução Americana, os escravos foram estimulados a participarem da luta com a promessa de alforria e terras. Como esse era um modo de escapar à crueldade dos senhores de escravos, muitos se aliaram aos regimentos britânicos nessa luta. Após a guerra e a rendição, esses escravos se uniram a dezenas de milhares de legalistas, ou seja, refugiados americanos que apoiaram a Coroa, e se estabeleceram na Nova Escócia. A massa humana que lá chegou era formada por soldados, civis, escravos e, inclusive, ameríndios.

As primeiras ondas migratórias de refugiados ocorreram em 1783 e 1874, anos em que muito da ação romanesca é narrada. O fluxo de pessoas demandou a criação de duas importantes colônias, New Brunswick e Cape Breton, que se tornam, assim, cenário de parte da narrativa. Cerca de 3.000 legalistas negros, cujos nomes foram registrados no "Livro dos Negros", fundaram a comunidade de Birchtown.

A trajetória da protagonista, personagem totalmente ficcional, abrange estadas em três continentes: África, Europa e América do Norte. No romance, o trânsito territorial corresponde também a um trânsito identitário, uma vez que, ao buscar se adaptar às culturas locais, a personagem passa pelo fenômeno da hibridização.

\section{Deslocamento e identidade: o sujeito diaspórico em $O$ livro dos negros}

O conceito de diáspora envolve, como afirma Said (2003, p. 46), a expulsão coletiva ou individual de pessoas de sua terra natal - o lugar antropológico, que é identitário, relacional e histórico (AUGÉ, 1994) - provocando, assim, uma fratura incurável, uma cisão que provoca imensa tristeza e melancolia. Em consequência, o sujeito diaspórico, ainda que impossibilitado de fazê-lo, anseia pelo retorno. A argumentação de Said gira em torno das transformações interiores que esse indivíduo experimenta, embora não se detenha no deslocamento em si, aspecto que também abordaremos neste trabalho.

A experiência da migração forçada levou os negros capturados a uma redefinição identitária, ou seja, à construção de novas formas de ser, agir e pensar no mundo, e à consequente construção de uma memória no entre-lugar da diáspora.

O livro dos negros narra a história da escrava Aminata Diallo desde sua captura, em 1757, até sua velhice, em Londres. O romance está dividido em 4 livros, em que a narrativa se alterna entre presente e passado, ao sabor das lembranças da narradora-protagonista.

\subsection{As narrativas do passado}

Segundo Pierre Nora (1993, p. 15), o que hodiernamente chamamos de memória é, na realidade, o "estoque material daquilo que nos é impossível lembrar". 
Essa impossibilidade nos faz recorrer ao arquivo, buscando articular a história com a memória, seja ela pessoal ou coletiva. Uma vez que o arquivo é um repositório de memórias: individuais e coletivas, oficiais e não oficiais, lícitas e ilícitas, legitimadoras e subversivas (BRADLEY, 1999, p. 108-109), tentamos recontar e representar as histórias do passado por meio dele.

O formato memorialístico dado ao romance, como dito anteriormente, tem como objetivo, primeiro, aproximar-se estilisticamente das primeiras narrativas de escravidão. Em segundo lugar, a concessão de voz a uma escrava, dada a sua dupla exclusão, por ser negra e mulher, faz parte de um projeto do autor de tornar possível a eclosão de memórias subterrâneas, condenadas ao silenciamento pela história (POLLAK, 1992, p. 6). Essas memórias, construídas na fronteira entre o dizível e o indizível, são, via de regra, memórias traumáticas e envolvem os impasses da necessidade de narrar. Em O livro dos negros a narrativa tem a função primeira de servir de instrumento para a luta em prol da abolição, mas também de dar testemunho do horror e dar significado à existência da narradora.

Como cada um dos livros dos quais o romance se constitui se reporta a uma fase específica da trajetória da personagem, neste artigo, as questões inerentes ao deslocamento e à identidade na diáspora também obedecerão a esse critério.

\subsubsection{Livro 1: quando a terra é perdida para sempre}

A narrativa se inicia em 1802, em um tom memorialístico, quando a narradora autodiegética, já idosa, está para comparecer a uma reunião no Parlamento em favor da abolição da escravatura. Dada a preocupação dos abolicionistas com a sua idade avançada, ela empreende uma viagem pelos meandros da memória e reflete sobre a sua surpreendente condição de sobrevivente a todo o sofrimento que tivera de enfrentar ao longo da vida: "Deve haver uma razão para eu ter vivido em todas aquelas terras, sobrevivido a todas aquelas encruzilhadas, enquanto outros foram assassinados ou fecharam os olhos e simplesmente decidiram morrer” (HILL, 2014, Livro 1, Cap. 1, p. 1/7).

Aminata nascera em uma aldeia em Bayo, onde fora sequestrada quando menina, após assistir ao assassinato de seus pais. Em sua velhice, cuidada por pessoas estranhas e separada de seus filhos, lucidamente percebe que, apesar de estar em Londres para um propósito digno, os que a cercam ainda a veem como um elemento exótico, parte de um mundo considerado primitivo. Essa visão é corroborada pelas palavras de uma menina branca, com quem trava um diálogo: "Perguntou-me o que eu comia. Meu avô disse que aposta que você come elefante cru. Disse-lhe que, na verdade, eu nunca tinha dado uma mordida em um elefante, mas que houve épocas em minha vida em que tive tanta fome, que até tentaria" (HILL, 2014, Livro 1, Cap. 1, p. 3/7).

A conversa com a menina é o gancho para a narrativa. Aminata passa a escrever a história de sua vida e busca assegurar-se de que ela não será alterada: "Caso eu morra antes de terminar a tarefa, instruí John Clarkson, um dos abolicionistas mais pacatos, mas o único em quem confio, para não mudar nada" (HILL, 2014, Livro 1, Cap. 1, p. 4/7). Essa passagem refere-se claramente a um 
aspecto da publicação das slave narratives: a necessidade de um documento escrito por um abolicionista atestando a sua veracidade. Nessas primeiras narrativas, muito do que era relatado foi alterado de modo a conquistar a simpatia de um público leitor cristão.

O pai de Aminata, Mamadu Diallo, era fula ${ }^{2}$ e muçulmano, sua mãe, Sira Kulibali, era de origem bambara ${ }^{3}$. Mamadu era o único da aldeia a ter uma cópia do Alcorão e a saber ler e a escrever. Desde pequena, a narradora ajudava a mãe, que era parteira, a trazer crianças ao mundo e, na idade adulta, lamentava-se de não ter podido criar os seus próprios filhos.

A partir do relato de sua captura por um grupo de negros de outra etnia, o romance avança em meio à narração dos muitos dias e noites em que Aminata caminhara nua, junto a outros cativos, presa a um libambo, sem se alimentar e sem poder sequer rezar a Alá:

Na manhã seguinte, entre a primeira luz da manhã e o nascer do sol, tentei rezar novamente, mas outro captor bateu em mim com uma vara. Na noite seguinte, depois de mais uma surra, desisti de rezar. Eu havia perdido minha mãe, meu pai e minha comunidade (HILL, 2014, Livro 1, Cap. 3, p. 3/25).

Essa consciência de perda das relações com a comunidade onde nascera, entretanto, não é suficiente para provocar uma ruptura com as raízes, pois ela está determinada a não perder sua identidade e sua herança cultural.

Nessa longa caminhada, Aminata entra em contato com um jovem, Chekura, da aldeia de Kinta, que, muitos anos mais tarde, será seu marido. Aparentemente livre e apenas acompanhando o comboio, ele se afeiçoa à menina, procurando agradá-la. Nessas conversas, ele narra que, após a morte dos pais, fora vendido pelo tio e que aquela "era a terceira chuva em que os raptores usavam-no para ajudar na caminhada dos cativos até a grande água". Essa é a primeira vez em que Aminata ouve falar do oceano, onde presenciará atrocidades das quais jamais esquecerá.

Quando, finalmente, chegam ao cais e se deparam com a imagem imponente do navio, ela afirma que voltará. Nem mesmo a observação melancólica de Chekura, que afirma nunca ter visto um cativo retornar, a demove dessa certeza: “- Então, eu dormirei durante o dia e andarei à noite. Mas, ouça, meu amigo: eu voltarei" (HILL, 2014, Livro 1, Cap. 3, p. 22/25).

Segundo Safran (1991), a diáspora teve um efeito característico na maioria dos cativos, ensejando: a luta pela manutenção de uma memória coletiva; a existência de uma perspectiva comum e de uma visão mítica da terra natal; a crença de que a aceitação plena na sociedade hospedeira não é possível e o desejo de retorno à terra natal ancestral. Se a vontade de Aminata, expressa nessa passagem citada, ecoa o anseio dos cativos, a resposta de Chekura reflete a experiência de quem esteve, ainda que obrigatoriamente, a serviço dos captores.

Vijai Mishra (2007, p. 12) afirma que, "frequentemente os relatos diaspóricos" - e, consequentemente, a literatura sobre a diáspora - "evocam um momento de trauma na terra natal". No caso de Aminata, a experiência traumática na 
África está associada à violência que resultou em seu cativeiro e no assassinato de seus pais. Vida afora, a personagem carrega consigo a lembrança dos últimos momentos de vida de ambos. Porém, nada disso se compara a experiências posteriores, vividas dentro da embarcação e sob as ordens de seus futuros senhores.

Entristecida, ao ver que Chekura de guia também passara a prisioneiro, Aminata lança um último olhar à sua terra: "Havia montanhas a distância; uma delas erguia-se como um enorme leão. Mas toda a sua força estava presa à terra. Não podia fazer nada por nós na água" (HILL, 2014, Livro 1, p. 65/65).

O relato do trajeto de Aminata na passagem do meio, ou seja, na rota transatlântica do comércio de escravos, é tão contundente quanto os que constam das primeiras narrativas de escravos. Ao final do último capítulo do Livro 1, Aminata é atirada ao porão do navio e começa a pensar em si mesma como uma djeli, uma contadora de histórias tribal:

Quando fui carregada escada acima e jogada, como um saco de farinha, no convés do navio dos toubabus, busquei conforto imaginando que era uma djeli, e que precisava ver e me lembrar de tudo. Meu propósito seria testemunhar e preparar-me para depor. Papai não deveria ter ensinado sua filha a ler e escrever em árabe. Por que quebrou as regras? Talvez soubesse que algo estava por vir, e quisesse que eu ficasse pronta (HILL, 2014, Livro 1, Cap. 4, p. 1/38).

É como testemunha, na perspectiva que Émile Benveniste (1969) denominou superstes $^{4}$, que, na velhice, Aminata narra a sua saga e os terríveis eventos que faziam com que os sobreviventes tivessem pesadelos. É em honra dos que não sobreviveram que ela se dispõe a narrar o horror: "Ao contar minha história, lembro-me de todos os que não resistiram à bala de mosquete, aos tubarões e aos pesadelos; todos os que nunca encontraram um grupo de ouvintes, e os que nunca tocaram em uma pena e em um tinteiro" (HILL, 2014, Livro 1, Cap. 4, p. 2/38).

$\mathrm{O}$ fato de Aminata falar fulfulde e maninka confere-lhe certo favorecimento, uma vez que é a única a bordo capaz de comunicar-se com alguns dos cativos. Ao entrar no porão imundo, cheio de negros amontoados como animais, sua reação é de terror e espanto:

Os homens gritavam nas mais diversas línguas. Gritavam preces árabes, gritavam em fulfulde, em bamanankan e em outras línguas. Todos pediam as mesmas coisas: água, comida, ar, luz. Um deles clamava estar acorrentado a um morto. Sob a luz bruxuleante, pude vê-lo tocar o corpo inerte preso a ele, pé com pé. Gelei e quis gritar. Não, disse para mim mesma. Seja uma djeli. Veja e recorde-se (HILL, 2014, Livro 1, Cap. 4, p. 10/38).

$\mathrm{Na}$ África Ocidental, há castas específicas em que as pessoas são formadas para contar histórias e resguardar a genealogia (SANTOS, 2015). Aminata sabe que a função social do djeli é ser depositário da palavra e transmissor da tradição. Embora não pertença a nenhuma casta que a habilite para tal, ela sabe que a ela caberá narrar a tragédia que se abate sobre os escravos que viajam com ela naquele navio: 
Um dia, se acaso voltar para casa, talvez façam uma exceção e permitam que eu me torne uma djeli, uma contadora de histórias. À noite, na aldeia, enquanto o fogo brilhasse e os velhos bebessem chá açucarado, visitantes viriam de longe para ouvir minha curiosa história. Para ser uma djeli, era preciso ter nascido em uma família especial. Eu desejava isso, pela honra de aprender e contar as histórias da nossa aldeia e de nossos ancestrais [...]. Dizia-se que, quando um djeli morria, a sabedoria de uma centena de homens morria com ele (HILL, 2014, Livro 1, Cap. 4, p. 1/38).

O compartilhamento do sofrimento tornou-se um elo entre negros de diversas etnias, caracterizando-se como um dos traços do trauma coletivo (SPIVAK, 2006). Para os brancos que os aprisionavam, os escravos não eram mais do que animais e, por isso mesmo, buscavam identificar-se. Em meio à miséria de sua condição, dizer e ser chamado pelo próprio nome passa a ser o único traço de humanidade possível: "No escuro, os homens repetiram meu nome e diziam os seus, enquanto eu passava. Queriam que eu os conhecesse. Soubesse quem eram" (HILL, 2014, Livro 1, Cap. 4, p. 10/38).

Aminata se define em várias passagens do romance como uma migrante, um ser em permanente deslocamento. De fato, são muitos os lugares pelos quais passa e vive temporariamente. Quando chega à América, dois meses depois da captura, apenas dois terços dos escravos estão vivos. Muitos haviam morrido em uma tentativa de motim, outros se atiraram ou foram atirados ao mar:

Aqueles que foram eliminados do animal ondeante afundaram, rapidamente, para a morte, e nós, que permanecemos, apodrecemos mais devagar, enquanto o veneno corroía nossas entranhas. Ficamos com a besta até que a nova terra encontrou nossos pés [...]. Talvez aqui, nesta nova terra, permaneçamos vivos (HILL, 2014, Livro 1, Cap. 4, p. 38/38).

Assim como os imigrantes que se deslocam para outro país, movidos por necessidades econômicas, para escapar de conflitos bélicos ou perseguição religiosa, Aminata busca apenas sobreviver. Na Ilha de Sullivan, enfraquecida pela diarreia e abatida pelo horror que testemunhara, ela ainda tenta apegar-se à sua fé, mas logo desiste, pensando que Alá está muito distante de todos eles.

Ao ser, finalmente, levada ao mercado onde será vendida, Aminata se surpreende ao ver como as casas são organizadas:

$\mathrm{Na}$ minha terra, as cidades que eu conhecia eram formadas ao redor de um círculo, de modo que todos pudessem ficar juntos. Neste lugar, as pessoas andavam em todas as direções, em ruas empoeiradas, às vezes lado a lado [...]. Eu não acreditava poder encontrar o caminho certo em um lugar assim (HILL, 2014, Livro 2, Cap. 2, p. 7/18).

Tudo o que vê lhe causa estranheza: a cidade, os brancos, os negros que, surpreendentemente, andam livres por todo lado, a carregar mercadorias, mas, principalmente, a sujeira espalhada por todos os lugares: "As ruas e as sarjetas estavam cobertas de lixo. Frutas podres, gatos mortos, fezes humanas e carne esverdeada, tudo isso sendo selecionado por pássaros da morte, barrigudos, com 
grandes asas, que circulavam, rodeavam e faziam acrobacias no ar" (HILL, 2014, Livro 2, Cap. 2, p. 7/18).

Aminata percebe que terá de armar-se de coragem para resistir ao que a espera. O sofrimento faz com que amadureça muito cedo: "Queria tornar-me a mulher que crescia dentro de mim, para encontrar minha dignidade e nunca mais perdê-la" (HILL, 2014, Livro 2, Cap. 2, p. 7/18). Essa dignidade implicava também a manutenção das raízes. Não importa o quanto os proprietários de escravos tentassem separá-los de suas tradições, os escravos estavam determinados a não deixá-las desaparecer, o que permitiu o surgimento de uma cultura híbrida, sincrética, sob a estrita vigilância dos proprietários das plantações. Esse ato de criar uma cultura própria foi um ato de rebelião.

Até então, a visão que Aminata tinha do mundo que a cercava se resumia às diferenças tribais, aos dialetos usados pelos grupos étnicos que conhecia e à presença hegemônica dos toubabus, os brancos que os aprisionavam. Nunca havia pensado no território que havia deixado como algo maior; pois não tinha ideia do que era um continente. Essa concepção começa a tomar forma quando ela encontra um jovem negro que fala bamanankan. Estranhamente, ele não tem nenhuma marca que identifique a sua tribo e, logo, ela descobre que ele nascera naquela terra para onde tinha sido levada e que era filho de mãe bambana. Por meio dele, fica sabendo que todos os que vieram com ela no navio eram oriundos de uma terra imensa, denominada África, de onde ela, Aminata, também viera, e eram denominados africanos. Conforme afirma Boulukos, "Na África Ocidental [...] a diversidade de culturas é tão grande que qualquer identidade 'africana' ampla e generalizada seria incoerente; tal identidade só é possível após a chegada [a] um navio negreiro e a experiência da passagem do meio" (BOULUKOS, 2007, p. 248, minha tradução ${ }^{5}$ ). Essa descoberta de uma identificação comum, que ia além da identidade tribal, proporciona a Aminata um novo olhar sobre si mesma.

O homem lhe ensina outras coisas, como a importância de se alimentar, ficar forte e tornar-se valiosa: a receita para a sobrevivência no cativeiro. Ele também a adverte sobre o perigo de professar a sua fé nessa nova terra.

\subsubsection{Livro 2: uma identidade em transformação}

Comprada por Robinson Appleby, Aminata é levada à plantação de índigo onde passa a viver e a trabalhar como escrava. Devido à dificuldade de Georgia, uma cativa que lá estava há algum tempo, em pronunciar o seu nome, os outros escravos passam a chamá-la de Meena, nome que vem a definir a sua nova identidade: "Nesta nova terra, eu era africana. Nesta nova terra, eu tinha um nome diferente, dado por alguém que não me conhecia. Um novo nome para a segunda vida de uma menina, que sobrevivera à travessia do grande rio" (HILL, 2014, Livro 2, Cap. 3, p. 5/40).

Com a ajuda de Georgia, começa a aprender gullah ${ }^{6}$ e inglês. Na maior parte do tempo, é o capataz da fazenda, Mamed, um negro nascido na América, quem controla o trabalho dos escravos. Por meio de Georgia, Aminata descobre que o pai de Mamed era branco e que o vendera para Appleby. Pequena demais para 
compreender o que faz de um homem, independentemente de sua cor, dono de outros homens, ela faz muitas perguntas a Georgia, que tenta ensinar-lhe que a vida de um escravo se resume ao trabalho.

Aminata tem habilidades particulares, sabe semear usando o calcanhar e os dedos dos pés, sabe fazer partos e começa a se distinguir dos demais: "Nunca vi alguém da África aprender tão depressa [...] - Mas cuidado, garota. Se você souber demais, alguém poderá matá-la (HILL, 2014, Livro 2, Cap. 3, p. 21/40).

Por meio de Georgia, Aminata descobre um modo de obter notícias de Chekura, de quem fora separada na Ilha Sullivan: o arrastão. Segundo a escrava, "as bocas dos negros são como rios" (HILL, 2014, Livro 2, Cap. 3, p. 19/40). Em seus trajetos, eles trocam informações. Enquanto espera por notícias, ela continua a aprender a produzir a tintura que os brancos tanto apreciavam.

Quando Mamed descobre que Aminata também é muçulmana, começa a ensinar-lhe, secretamente, a ler e a escrever em inglês. Os conhecimentos de Mamed sobre a produção de índigo faziam dele um escravo especial e, por isso, tinha algumas regalias, como o acesso a livros. Georgia lhe ensinara como sobreviver na terra dos brancos, mas Mamed era o único capaz de dar-lhe condições de escapar e voltar à sua terra.

O arrastão faz com que Chekura descubra onde ela está e venha vê-la muitas vezes. Atento às visitas, Appleby violenta Aminata, que, a partir de então, começa a articular um modo de fugir e voltar para a África:

Sabia que precisaria entender a língua dos buckras para sobreviver entre eles, por isso, devorava as lições de Mamed. Logo, eu podia ler tão bem quanto ele, e não havia muito mais que ele pudesse me ensinar. Foi desapontador saber que Mamed não tinha ideia de como uma pessoa poderia chegar à África. A única coisa que dizia era que nunca ouvira falar de um escravo que tivesse voltado para lá, ou sequer tentado fazê-lo (HILL, 2014, Livro 2, Cap. 4, p. 2/22).

Por muito tempo, seguindo o conselho de Mamed, Aminata consegue ocultar o fato de que havia aprendido a ler e a escrever em inglês, até que Appleby recebe a visita de Solomon Lindo, o inspetor de índigo da Carolina do Sul e, na presença dele, utiliza o inglês conforme é falado pelos brancos. Isso desperta a curiosidade de Lindo, que, por meio de um ardil, confirma que ela sabe ler. Entretanto, ele não a denuncia.

Algum tempo mais tarde, já com dezesseis anos, Aminata dá à luz um filho de Chekura, mas, quando o bebê completa 10 meses, Appleby o vende e ela jamais o encontra novamente. Abatida, Aminata entrega-se à apatia. Vendo que ela não mais será útil, Appleby a vende para Solomon Lindo.

A separação de familiares foi uma estratégia usada pelos senhores de escravos para evitar levantes. Se, por um lado, a perda de um filho e o distanciamento do marido fora um dos momentos mais trágicos da sua existência, por outro, a vida com os Lindo em Charles Town mostra-se suportável. Objetivando explorar a capacidade de Aminata, Solomon ensina-lhe aritmética e o sistema monetário, 
de modo que esta passa a escriturar os seus livros contábeis e também a fazer partos de modo autônomo.

Apesar de ser bem tratada, Aminata não desiste da ideia de retornar à África e fica frustrada quando Lindo lhe mostra um mapa do continente africano, pois, ao invés de encontrar os nomes das aldeias conhecidas, havia vastos espaços vazios com figuras de animais selvagens. Essa passagem evidencia a ignorância dos cartógrafos de então; mas também demonstra que, assim como o seu lugar de nascimento, ela é inexistente aos olhos do império. Aminata conclui que precisará compreender "o mundo dos brancos bem o bastante para descobrir como sair dele (HILL, 2014, Livro 2, Cap. 5, p. 28/28).

Em 1775, as colônias foram assoladas com surtos de varíola e sífilis e o número de mortos aumentou tanto que os navios negreiros foram proibidos de atracar na Ilha de Sullivan. Nesse contexto, Aminata e Chekura se reencontram depois de muitos anos. Ele fora enviado à Georgia pouco antes de o filho de ambos ter sido vendido e desde então, tinha estado à procura da mulher. Agora com 30 anos, ela reflete sobre o tempo perdido. Por meio dele, ela vem a saber que seu filho fora vendido para um dono de plantation da Georgia e que, cerca de um ano depois, morrera de varíola. Para a tristeza de Aminata, ela descobre que seu senhor, Lindo, fora o intermediário da venda.

\subsubsection{Livro 3: um ensaio de liberdade}

Com a partida de Chekura para Low Country e as dificuldades financeiras de Lindo, Aminata passa fome pela primeira vez desde que chegara a Charles Town. Em uma tentativa de reerguer-se financeiramente, Solomon Lindo vai a Nova York e a leva para escrever cartas e atualizar os seus livros. Em Manhattan, a caminho do local onde ficariam hospedados, Aminata vê pela primeira vez o local onde em breve irá morar, Canvas Town, um amontoado de tendas e barracos, habitados por negros.

No hotel, Aminata é encarregada de fazer seu registro e exulta ao poder assinar o seu próprio nome:

[...] escrevi meu nome no livro de registros: Aminata Diallo. Considerei o fato de poder escrever meu nome verdadeiro na cidade de Nova York um bom sinal. O simples ato de escrevê-lo, movimentando a pena com delicadeza e segurança, na caligrafia que a Senhora Lindo tão pacientemente me ensinara, selou um contrato particular que eu havia feito comigo mesma. Eu escrevera meu nome em um documento público, e era uma pessoa, com o mesmo direito à vida e à liberdade quanto o homem que dizia me possuir. Eu não voltaria a Charles Town (HILL, 2014, Livro 3, Cap. 2, p. 4/39).

Com Sam, o dono do hotel, Aminata obtém informações sobre onde esconder-se se vier a fugir, mas, para sua tristeza, descobre que não há navios para a África partindo de Nova York. Ela teria de ir à Inglaterra e correr o risco de ser aprisionada novamente. Naquele mesmo dia, o confronto entre britânicos e cidadãos das colônias começa a agravar-se e, por sugestão de Sam, que lhe dá um 
cobertor e alimentos, ela foge e se esconde na floresta. Esse é o momento em que recupera a liberdade.

Após a partida de Lindo, Aminata passa a ajudar Sam no hotel em troca de comida e abrigo e começa a ensinar os escravos a ler e a escrever na Igreja Trinity. Com a ajuda de uma de suas alunas, consegue material suficiente para construir um barraco em Canvas Town.

Cerca de um ano depois, Aminata lê em um jornal que Lord Dunmore, governador do estado da Virgínia, prometia liberdade aos negros que estivessem dispostos a lutar junto aos britânicos na guerra. Durante os sete anos em que os britânicos retomaram Manhattan, os negros capazes obtiveram emprego e Aminata voltou a ser paga para fazer partos e, algumas vezes, provocar abortos com ervas medicinais.

Com a rendição britânica, em 1782, vários senhores de escravos começaram a fazer incursões nos locais habitados por negros, como Canvas Town, em busca de mão de obra para as fazendas. A promessa de terras e liberdade faz com que os negros aceitem a proposta dos britânicos, que estão em retirada, para formar uma comunidade em Nova Escócia, uma das colônias situada onde hoje é o Canadá.

Graças aos seus conhecimentos das línguas africanas, Aminata é convocada para ajudar a divulgar e a registrar os nomes dos escravos. Nesse mesmo dia, Chekura reaparece, depois de nove anos, e ambos decidem ir juntos para a Nova Escócia. Enquanto esperam a data do embarque, Aminata trabalha no registro dos passageiros dos navios e percebe que muitos brancos estão entre os legalistas. Quando, finalmente, permitem o seu embarque, ela está grávida novamente. Entretanto, Chekura é obrigado a seguir sozinho para Annapolis Royal, porque alguém havia reclamado a posse de Aminata. Alguns dias mais tarde, ela descobre que Appleby havia tido notícias de seu paradeiro e se apresentara como seu dono. A confusão só se desfaz quando Lindo aparece e atesta ser ele o seu senhor, libertando-a em seguida.

Os negros legalistas logo descobrem que sua situação em Nova Escócia não seria muito diferente da que tinham na América, pois a promessa não foi cumprida. Sozinha em um lugar estranho, Aminata recorre novamente às suas habilidades para sobreviver: amparar crianças e ensinar as pessoas de Birchtown a ler.

Conforme afirma John Berry (2004), o modelo mais comum de aculturação é integrativo e ocorre quando o migrante adota práticas culturais do país de acolhimento sem abrir mão de suas raízes. No romance, é possível observar que mesmo estando longe de sua terra e em meio a pessoas de diversas culturas, Aminata ainda preserva algo de suas origens, como a recusa a comer carne de porco por motivos religiosos.

Com o passar do tempo, Aminata percebe que se não soubesse ler e escrever em inglês, jamais teria conseguido sobreviver. Assim, quando recebe notícias de negros fugitivos recapturados e de outros tantos que morreram de fome ao relento, Aminata conversa com o filho ainda no ventre: "nunca deixarei que prendam, com um contrato, nem a mim nem a você [...]. A primeira coisa que pretendo ensiná-lo é de onde vim e quem é o seu povo. A segunda é ler e escrever (HILL, 2014, Livro 3, Cap. 4, p. 13/18). 
Outro traço de aculturação de Aminata é a adesão à comunidade em que se encontra. Fora assim em Canvas Town e o mesmo se repete em Birchtown. Como os demais, ela comparece aos cultos dirigidos por Papai Moses, um velho escravo que é o líder comunitário, mas não sem usar seu senso crítico:

Duas vezes por semana, eu assistia aos serviços de Papai Moses. Reclinado sobre o púlpito de modo a ficar em pé sem ajuda, ele gritava e se esgoelava até ficar rouco. Às vezes, seus olhos se reviravam e ele caía para trás, nos braços de dois diáconos. Nos bancos da igreja, os congregantes davam pulos, agitavam-se e desfaleciam. Nunca me vi renascida dessa maneira, mas enquanto os outros ficavam extasiados, eu pensava em meu pai lendo o Alcorão, e perguntava-me o que pensaria ele sobre tais arroubos de piedade (HILL, 2014, Livro 3, Cap. 4, p. 14/18).

A passagem de Aminata por Birchtown traz-lhe vários momentos dolorosos. Sem notícias de Chekura, ela dá à luz uma menina, May, e, por algum tempo, sente-se feliz. Quando começa a trabalhar para o casal Whiterspoon, sequer pode imaginar que eles partiriam para Boston levando sua filha com eles.

Nos quatro anos seguintes, Shelburne entra em decadência e muitos legalistas fecham seus negócios e voltam para os Estados Unidos. Somente os negros de Birchtown ficam e Aminata permanece com eles até que surge o Tenente John Clarkson propondo-lhes um retorno à África, onde formariam uma colônia, receberiam terras, sementes para o plantio e gozariam de igualdade política e racial. Como em outras vezes, Aminata é convocada para fazer as anotações e, em 1791, acompanha-o a Halifax, onde recebe a notícia da morte de Chekura no naufrágio do navio Joseph.

\subsubsection{Livro 4: o caminho de casa}

A história de Aminata é feita de dor e superação. Sua viagem para a África, a bordo do Lucretia, conquanto perigosa, em nada se assemelha à travessia da passagem do meio. É com emoção que vê os contornos de sua terra ao longe, na chegada:

Meus olhos esquadrinharam as montanhas verdes. De minha infância, lembrei-me do perfil das costas e da cabeça do leão. Serra Leoa - a Montanha do Leão - ergueu-se tão nitidamente na península, que meu desejo era tocá-la [...] até que a costa com a montanha em forma de leão surgisse, eu duvidava que voltasse para o local de onde havia partido. Seria esperar muito (HILL, 2014, Livro 4, Cap. 1, p. 1/24).

No caso específico da diáspora africana, a perspectiva do retorno era praticamente impossível, razão pela qual os sujeitos diaspóricos buscavam encontrar meios de manter viva a memória étnica, ainda que em diálogo com as práticas da sociedade hospedeira.

Aminata sempre soubera estabelecer o diálogo entre culturas, adaptando-se às situações que surgiam, tendo em mente o firme propósito de voltar à sua terra 
natal. No entanto, naquele momento, desprovida de sonhos e longe das pessoas que amava, sente-se vazia.

Logo, os negros de Birchtown tomam conhecimento de que o local onde estão é muito próximo da Ilha de Bance, de onde os traficantes partem nos navios negreiros, e ficam receosos, mas são acalmados com promessas de autossuficiência e liberdade.

Para estabelecer a colônia de Freetown, os negros que vieram da Nova Escócia tiveram de construir casas, igrejas, armazéns e estradas, porém sempre nos limites da cidade, pois a Companhia de Serra Leoa não tinha como protegê-los além deles. Mais realista do que os demais, Aminata tem certeza de que "nenhum lugar do mundo era totalmente seguro para um africano e, para muitos [...] a sobrevivência dependia de uma eterna migração" (HILL, 2014, Livro. 4, Cap.1, p. 10/24). Intimamente, ela percebe que aquela é mais uma etapa da sua peregrinação pelo mundo e o início de uma outra versão identitária:

Na Carolina do Sul consideravam-me africana. Na Nova Escócia, tornara-me legalista ou negra, ou ambos. De volta à África, era vista como nova-escocesa, e, em alguns aspectos, era mesmo. Certamente, eu era mais nova-escocesa do que africana quando as mulheres temnes agruparam-se ao meu redor, com cereais e aves penduradas e cestos de frutas equilibrados na cabeça (HILL, 2014, Livro 4, Cap. 1, p. 11/24).

A fim de poder comunicar-se com o povo local, os temnes, os únicos que poderiam levá-la ao interior e à sua aldeia, Aminata aprende a sua língua:

Mas mesmo aprendendo, diariamente, novas palavras e frases, perguntava-me quem exatamente era eu e o que me tornara, após mais de trinta anos nas colônias. Sem meus parentes, meu marido, filhos ou qualquer pessoa com quem falar as línguas de minha infância, que parte de mim ainda era africana? Eu não me sentiria em casa até que voltasse para Bayo (HILL, 2014, Livro 4, Cap. 1, p. 11/24).

Assim como acontecera na Nova Escócia, os britânicos não honram o compromisso e os colonos se vêem novamente em uma relação de dependência absoluta. Ao invés da liberdade e da autonomia econômica, encontram-se em uma condição de trabalho forçado. Aminata se adapta a essa nova realidade, pensando em Freetown como uma ponte para o reencontro com seu verdadeiro lar.

Anos mais tarde, com a ajuda de um médico que viajava nos navios negreiros, ela descobre que o único modo de voltar a Bayo é acompanhar o trajeto dos traficantes de escravos. Mesmo sendo advertida sobre o risco de ser capturada e vendida novamente, decide fazer um acordo com um traficante e segue com o grupo. No meio da viagem, ela os ouve conversando em fulfulde e descobre que pretendem vendê-la. À noite, ela foge e consegue a ajuda de um pastor de cabras. Enquanto tenta se fortalecer para voltar a Freetown, ela finalmente exerce a função que tanto desejara: a de uma djeli, narrando a sua própria história e a de todos aqueles que cruzaram o seu caminho. 
Ao longo do mês em que recebe abrigo do pastor e sua família, descobre que o seu maior desejo não é mais voltar a Bayo, mas continuar livre e ajudar outros a conquistarem a liberdade. Finalmente, percebe que o único modo de fazê-lo é aceitar a oferta de Clarkson, ir a Londres e contar aos abolicionistas o que lhe acontecera quantas vezes houvesse necessidade.

Nesse capítulo, fica clara a intenção de Lawrence Hill de usar a política do retorno dos sujeitos diaspóricos negros à África para expor um sistema colonial corrupto. A sobrevivência de Aminata deveu-se unicamente à sua capacidade de adaptação e à sua inteligência.

\subsection{A narrativa do presente}

No romance, a narrativa do presente é fracionada, restringindo-se a capítulos isolados em cada um dos quatro livros. No Livro 1, o capítulo intitulado "E agora sou velha", situado temporalmente em 1802, serve de introito à narrativa.

O capítulo "E minha história aguarda como uma fera adormecida" se passa em 1803 e é um relato da tentativa dos abolicionistas em persuadi-la a escrever sua história sem, no entanto, incorrer em uma defesa direta da abolição da escravatura. Em seu ponto de vista, as conquistas deveriam ser paulatinas, mas Aminata não consegue entender o motivo.

Em "Nações tão abençoadas quanto você", no Livro 3, cujo recorte temporal é o ano de 1804, Aminata é obrigada a acompanhar os abolicionistas em um culto da igreja anglicana. Entediada, ela não se furta a fazer comparações com os cultos que assistiu em Birchtown:

Ninguém vai me convencer a visitar uma igreja anglicana, nunca mais nesta vida. Se Deus tiver de ser saudado, que seja entre os batistas de Birchtown ou Freetown. Pelo menos eles dançam quando clamam por Jesus, e gritam tão alto que até os semimortos ficam acordados (HILL, 2014, Livro 3, Cap. 1, p. 3/6).

O último capítulo do Livro 4, "A grande djeli da academia", narra a chegada de Aminata a Londres, no ano de 1802. A sensação de espanto da protagonista encontra paralelismo nas impressões que tivera no dia em que chegara a Ilha de Sullivan. Os contrastes entre as colônias e a metrópole causam estranheza em uma mulher que passara a vida em trânsito, tendo de reinventar-se em cada lugar de passagem:

Os brancos de Freetown eram homens da Companhia e suas esposas, vivendo nas melhores residências, recebendo os melhores salários e comendo as melhores provisões. Mas na Inglaterra... Na Inglaterra... Vi um homem aleijado, usando pedaços de pau no lugar de muletas, com a mão espalmada pedindo dinheiro. Vi cegos esmolando, vi filhos de mulheres mutiladas, sujos e com o nariz escorrendo em todas as esquinas. Parecia que metade de todos os ingleses tinha, pelo menos, um dente podre, escuro e inflamado. Vi pessoas mal-agasalhadas, tremendo de frio, tossindo, 
espirrando e morrendo. Homens em roupas rasgadas tinham de pular, às vezes em valas fétidas, quando cavalos e carruagens vinham de encontro a eles. Gritos, pedidos e acusações enchiam meus ouvidos. $\mathrm{O}$ ar tinha um cheiro acre de madeira queimada, comida podre e carne jogada das portas das lojas (HILL, 2014, Livro 4, Cap. 5, p. 2/22).

Alguns dias mais tarde, ela é levada à sede do Comitê para a Abolição do Tráfico de Escravos e reage quando um dos homens presentes diz que eles escreverão um relato da sua vida: “- Sem orientação, muito obrigada. Minha vida, minhas palavras, minha caneta. Sou capaz de escrever" (HILL, 2014, Livro 4, Cap. 5, p. 8/22). Esta passagem do texto aponta para a crença vigente à época de que os negros possuíam menor faculdade mental. Ser capaz de escrever as próprias memórias, como afirmam Nakanishi e Nigro (2019, p. 81), é uma forma de provar sua capacidade intelectual e pôr em xeque o estereótipo de ser não pensante. Nas slave narratives havia sempre a necessidade de um prefácio escrito por um branco e alguma forma de autenticação atestando o caráter e a credibilidade do escravo. Por meio do romance, o autor contesta essa prática.

Os traficantes tentavam manter seus negócios afirmando que a escravidão era uma instituição humanitária, que resgatava os africanos das barbáries cometidas em sua terra. Mediante tais afirmações, ela sente o quão imperioso é o seu desejo de narrar. Diante de membros do comitê e jornalistas, ela conta a própria história com riqueza de detalhes e entrega uma versão escrita do seu relato.

Em meio aos curiosos que a esperam todos os dias à saída do comitê, Aminata vê o rosto de uma jovem negra que lhe diz algo que não compreende. Repreende a si mesma imediatamente, proibindo-se de sonhar. O sonho se torna realidade quando, nesse mesmo dia, a jovem a procura na casa onde está hospedada e se identifica como May, a filha que Aminata julgava perdida para sempre.

Os Whiterspoon nunca haviam mudado o seu nome, nem esconderam que ela fora, segundo eles, "adotada", mas alegavam que tinha sido abandonada por uma africana. May tinha vaga lembrança de Aminata, e, desde o início, questionava a história. Os Whiterspoon levaram-na de Shelburne para Boston, e, de lá, para a Inglaterra. Com o tempo, a afeição pela menina se desfez e, em Londres, ela era tratada como uma criada. Aprendera a ler e a escrever, a servir refeições e a fazer as tarefas domésticas e, embora nunca tenha sido chamada de escrava, jamais recebera pagamento pelos seus serviços. Quando fugiu de casa, aos 11 anos, foi acolhida por um pregador e sua esposa e ganhava a vida lecionando em uma escola para negros pobres.

Aminata tem, assim, parte dos seus desejos realizados, contudo se decepciona quando descobre que a sua história não foi usada na luta pela abolição da escravatura, mas apenas para uma moção pelo fim do tráfico negreiro ${ }^{7}$.

O capítulo se encerra com a decisão de negar aos abolicionistas a reivindicação de publicar a sua história, uma vez que desejam corrigir as partes que não conseguem comprovar. No capítulo dois, ela já cogitava o que aconteceria com o seu relato depois da sua morte: 
Se eu viver tempo suficiente para acabar minha história, esta sobreviverá a mim. Tempos depois que eu tiver retornado ao espírito de meus ancestrais, ela talvez espere na Biblioteca de Londres. Às vezes, imagino o primeiro leitor que se deparar com a minha história. Será uma garota? Talvez uma mulher. Um homem. Um inglês. Um africano. Uma dessas pessoas encontrará minha história e a passará adiante. $\mathrm{E}$ então, creio, terei vivido por uma razão (HILL, 2014, Livro 2, Cap. 1, p. 5/5).

O fim do romance aponta para essa razão: o amor à liberdade e a necessidade de narrar.

\section{Considerações finais}

Ao longo do artigo, buscamos demonstrar que O livro dos negros, cuja temática é a trajetória de escravos durante a vigência do sistema escravagista, é uma neonarrativa de escravidão contemporânea.

Se comparadas às narrativas de escravos tradicionais, que se configuravam como meras autobiografias, as neonarrativas são, em essência, uma forma de ficção histórica, mais especificamente, metaficções historiográficas e trazem no bojo uma análise crítica de um dos mais trágicos eventos da história humana.

No caso específico de O livro dos negros, Lawrence Hill aceita o desafio ético e estético de reimaginar o período da escravidão na perspectiva de um autor do século XXI e busca explorar aspectos da história da diáspora africana que têm sido sistematicamente ignorados, suprimidos ou esquecidos. Por muito tempo, os registros do arquivo histórico consistiram em narrativas mestras, elaboradas por um poder hegemônico que negou aos negros escravizados o papel de agentes ativos na formação da cultura afro-americana.

Em seu romance, Hill promove a reescrita da Revolução Americana na perspectiva de um grupo social excluído e desconstrói concepções largamente difundidas como, por exemplo, a de que o Canadá foi um "paraíso" para os negros durante o período da escravidão. Essa versão é refutada com a narração do desamparo, da violência e da discriminação sofridas pela protagonista na Nova Escócia.

Detentora da voz, a protagonista revela como as memórias subterrâneas, ao eclodir, colidem com o discurso oficial e, por vezes, são por ele modificadas. O relato de Aminata Diallo abrange a sua vivência em três continentes, bem como as transformações às quais está exposto o sujeito diaspórico, dando ênfase à relação entre a identidade, compreendida aqui como construto discursivo, e as práticas culturais. Em sua trajetória, Aminata desenvolve estratégias de identificação que possibilitam o diálogo com culturas diferentes da sua. À medida que o tempo passa, fica mais evidente que a pátria perdida é irrecuperável. Não só porque, ao longo de décadas, nenhum lugar permanece o mesmo, mas, principalmente, porque, na condição de migrante, ela também não é mais a mesma pessoa.

A própria valorização do relato como elemento modificador do establishment, implícita no título do capítulo "A grande djeli da academia", está associada à transformação identitária da protagonista, cuja vontade primeira era de ser apenas 
a contadora de histórias tribal e transmissora da tradição. O empoderamento de Aminata se dá por meio do discurso.

Com O livro dos negros, Hill demonstra que o arquivo histórico pode e deve ser reinterpretado, porque esse olhar diferenciado sobre a memória e as identidades exerce também uma forma de poder (SCHWARTZ, 2006, p. 3) que, conferido à literatura, torna-se transformador e vital para a luta contra a opressão racial.

Notas

1. O registro pode ser acessado em: http://epe.lac-bac.gc.ca/100/200/301/ic/can_ digital_collections/blackloyalists/index.htm

2. Os fulas ou fulanis são um grupo étnico que compreende várias populações espalhadas pela África Ocidental, mas também a região central do continente e o Sudão.

3. Conforme nota da tradutora, os Bambaras (Bamana na sua própria língua ou, algumas vezes, Banmana) são um grupo étnico mandés que vive no Oeste da África, principalmente no Mali, mas também na Guiné, Burkina Faso e Senegal.

4. Benveniste distingue dois tipos de testemunho: testis (terceiro), daquele que viu e testemunhou a cena dolorosa, ou superstes (primeiro), daquele que viveu e testemunha sua própria experiência.

5. No original: "Within West Africa [...] the diversity of cultures is so great that any broad, generalized 'African' identity would be incoherent; such an identity is only possible [...] after [the] arrival on a slave ship and experience of the middle passage" (BOULUKOS, 2007, p. 248).

6. A língua gullah é uma língua crioula de base inglesa, com fortes influências de línguas da África Ocidental e Central, falada pelos povos gullah, uma população afro-americano que vive nas Sea Islands e na região costeira dos estados norteamericanos da Carolina do Norte, Carolina do Sul, Geórgia e no Nordeste da Flórida.

7. O tráfico negreiro foi abolido pelo Parlamento Britânico em 1807.

\section{Referências}

AUGÉ, Marc. Não-lugares: introdução a uma antropologia da sobremodernidade. Tradução de Lúcia Mucznik. Rio de Janeiro: Bertrand Editora, 1994.

BELL, Bernard W. The Afro-American Novel and Its Tradition. Amherst: University of Massachusetts Press, 1987.

BENJAMIN, Walter. Magia e técnica, arte e política: ensaios sobre literatura e história da cultura. Tradução de Sérgio Paulo Rouanet. São Paulo: Brasiliense, 1987.

BENVENISTE, Émile. Vocabulaire dês intitutions indo-européenes: 2. Pouvoir, droit, religion. Paris: Les Editions de Minuit: 1969.

BERRY, J. W. Migração, Aculturação e Adaptação. In: DEBIAGGI, Silvia Dantas; PAIVA, Geraldo José de. Psicologia, E/Imigração e Cultura. São Paulo: Casa do Psicólogo, 2004, p. 29-45.

BOULUKUS, George E. Olaudah Equiano and the Eighteenth-Century Debate on Africa. Eighteenth-Century Studies, v. 40, n. 2, p. 241-255, inverno, 2007.

BRADLEY, Harriet. The Seductions of the Archive: Voices lost and found. History of the Human Sciences, v. 1, n. 2, p. 107-122, 1999. DOI: https://doi. org/10.1177/09526959922120270 
DAVIS, Charles T.; GATES, Henry Louis, Jr. (Eds.). The Slaves' Narrative. Nova York: Oxford University Press, 1991.

HILL, Lawrence. O livro dos negros. Tradução de Dina Blaj Shaffer. São Paulo: Primavera Editorial, 2015.

HUTCHEON, Linda. Poética do pós-modernismo. Tradução de Ricardo Cruz. Rio de Janeiro: Imago, 1991.

JOHNSON, Erica. Building the Neo-Archive: Dionne Brand's A Map to the Door of No Return. Meridians: feminism, race, transnationalism, v. 12, n. 1, p. 149-171, 2014. DOI: https://doi.org/10.2979/meridians.12.1.149.

MISHRA, Vijay. The Literature of the Indian Diaspora: Theorizing the diasporic imaginary. Londres, Nova York: Routledge, 2007.

MISRAHI-BARAK, Judith. Post-Beloved Writing: Review, Revitalize, Recalculate. Black Studies Papers, v. 1, n. 1, p. 37-55, 2014.

MORRISON, Toni. Beloved. Nova York: Knof, 1997.

NAKANISHI, Débora S.; NIGRO, Cláudia Maria C. A escravidão presente na literatura afro-americana: três séculos observados. Aletria: Revista de Estudos de Literatura, Belo Horizonte, v. 29, n. 2, p. 63-78, jun. 2019. DOI: http://dx.doi. org/10.17851/2317-2096.29.2.63-78.

NORA, Pierre. Entre Memória e História - A problemática dos lugares. Tradução de Yara Aun Khoury. Projeto História, São Paulo, v. 10, p. 1-22, dez, 1993.

POLLAK, Michael. Memória e Identidade Social. Tradução de Monique Audras, Edição de Dora Rocha. Estudos Históricos, Rio de Janeiro, v. 5, n. 10, p. 200-212, 1992.

RUSHDY, Ashraf H. A. Neo-slave Narrative. In: ANDREWS, William L.; TRUDIER, Harris; FOSTER, Francis F. (Eds.). Oxford Companion to African American Literature. Nova York: Oxford University Press, 1997, p. 533-535.

SAID, Edward. Reflexões sobre exílio e outros ensaios. Tradução de Pedro Maia Soares. São Paulo: Companhia das Letras, 2003.

SAFRAN, William. Diasporas in Modern Societies: Myths of Homeland and Return. Diaspora: A Journal of Transnational Studies, v. 1, n. 1, p. 83-99. University of Toronto Press, Spring, 1991.

SANTOS, Toni Edson Costa. Negros pingos nos "is": djeli na África ocidental; griô como transcriação; e oralidade como um possível pilar da cena negra. Urdimento: Revista de Estudos em Artes Cênicas, Florianópolis, v. 1, n. 24, p. 157-173, 2015. DOI: https://doi.org/10.5965/1414573101242015157.

SCHWARTZ, Joan M. Having New Eyes: Spaces of Archives, Landscapes of Power. Archivaria: The Journal of the Association Canadian Archivists, n. 61, p. 1-25, 2006.

SPIVAK, Gayatri Chakravorty. Conversations with Gayatri Chakravorty Spivak. With Swapan Chakravorty, Suzana Milevska, and Tania E. Barlow. Londres: Seagull, 2006.

TORRES, Sonia; PAIVA, Rita de Cássia Marinho de. Mal de arquivo em Linden Hills. Ilha do Desterro, Florianópolos, v. 72, n. 1, p. 125-143, 2019. DOI: https:// doi.org/10.5007/2175-8026.2019v72n1p125

WALKER, Margaret. Jubilee. Nova York: Mariner Books, 1966.

Recebido em: 14/06/2020

Aceito em: 27/08/2020 